原著鍼治療による反復性扁桃炎の予防に関する 臨床的研究 (第 3 報)

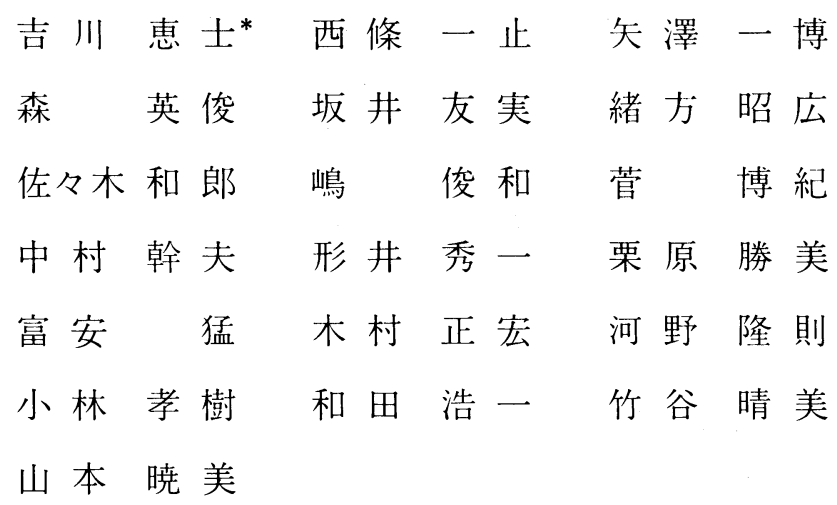

要旨 筆者らは, 反復性扁桃炎の再発予防を目的とし，鍼治療を行っ ている。昭和55年度239例の患者を扱い, 121例に効果を認め, 中でも 小学生に効果の高いことが明らかとなった。そこで今回は再発予防効 果に自然治癒がどの程度あるかを検討するため, 厳密な対照群として は問題があるが，扁桃肥大児を学校調查により選び銊治療を行った扁 桃炎患児と，年間欠席日数および体格について比較した。

その結果，昭和58年 5 月現在調査が終了した例数は，鍼治療扁桃炎 患児は22例，非鍼治療扁桃肥大児は19例であった。鍼治療扁桃炎患児 の治療前 1 年間の欠席日数は, $\mathrm{S}$ 校全児童の欠席日数の平均より多く, 平均 14.0 日であり，鍼治療後 1 年間のそれは, 6.5 日と $\mathrm{S}$ 校全児童の平 均に近以した。非銊治療扁桃肥大児の欠席日数は， 2 年間共 $\mathrm{S}$ 校全児 童の平均に近かった。

鍼治療扁桃炎患児の治療開始時の体格は，身長において14例中 8 例, 体重においては14例中12例が全国平均より低值を示した。非銊治療扁 桃肥大児の体格は，全国平均に近かった。鍼治療扁桃炎患児では，治 療後 1 年間に 14 例中 6 例は身長・体重ともに，14例中 2 例は身長に, 14例中 1 例は体重に全国平均に上まわる増加傾向を認めた。

以上のことから, 扁桃炎患児は例之病巣扁桃の心配がなくとも, 教 育上・発育上問題をもっていることが明らかとなった。扁摘における 生体への侵しゅう度や，入院による医療と負担および家族の負担を考 えるとき，鍼治療は，たと之扁摘ほど効果が確実でないとしても，扁 摘の前に試みるに充分価する治療方法であると考える。 


\section{I 緒言}

筆者らは，鍼治療による反復性扁桃炎の発熱予 防効果について検討し，第 2 報で以下のように報 告した。

（1）週 1 回合計 3 回の銊治療は, 扁摘ほど有効 率は高くないが，生体への侵しゅう度・医療 費・入院にかかわる家族の負担などを扁摘と 比較すると，反復性扁桃炎の発熱予防を目的 とした保存療法としてファーストチョイスさ れる方法である。

（2）年令別には，6〜11歳(小学生)の小児にお いて発熱予防効果が最も高かった。

（3）発熱予防効果の良かった症例では，のどの 調子，鼻の調子，体全体の調子などが良くな った。風邪をひきにくくなったなど全身状態 の改善を認めた。

以上の結果から次のように考察し課題を設定し た。

（1） 6 歳～11歳という小児期は，自然治癒力か 最も盛んな時期であり，とくに扁桃はそれ自 体が小児期に旺盛な免疫㙨能を有しているこ とから，第 2 報で報告した成績には，自然治 癒が含まれており，鍼治療による反復性扁桃 炎の発熱予防効果において自然治癒がどの程 度関与しているかを検討しなければならない。

（2）鍼治療によって，発熱の予防効果とともに 全身状態の改善が認められたことは，銊治療 が反復性扁桃炎患児の体位（健康度・体格・ 体力）の向上に良い影響を与えているのでは ないかと推察されるため，鍼治療前後の体位 を比較する必要がある。

* Keishi YoshIKaWA 筑波大学理療科教員養成施設

共同研究者 : Kazushi Nishijo, Kazuhiro YazAWA, Hidetoshi Mori, Tomomi Sakai, Akihiro Ogata, Kazuo SASAKI, Toshikazu Shima, Hiroki Suga, Mikio NaKamuRA, Shuichi KataI, Katsumi Kurihara, Takeshi TOMIYASU, Masahiro KImURA, Takanori Kawano, Koki KoBaYashi, Koichi WadA, Harumi Taketani, Akemi YaMAMOTO 筑波大学理療科教員盖成施設

Key Words：反復性扁桃炎, 垍獚性扁桃炎, 発熱, 予防 医学, 鍼治療
そこで今回は，昭和 55 年度に鍼治療を行った反 復性扁桃炎の小学生のうち, 鍼治療後 1 年間の経 過を観察できた症例 (94例) と，昭和55年度に同じ 学校で同じ学年であった銊治療を行っていない反 復性扁桃炎患児とを対象とし，鍼治療による反復 性扁桃炎の発熱予防効果における自然治癒の関与 について，鍼治療前 1 年間と鍼治療後 1 年間の出 席日数・欠席日数を比較した。また体位の向上に ついては, 鍼治療前 1 年間と鍼治療後 1 年間の体 格の増加量を比較した。

\section{II 研究対象および方法}

\section{1. 研究対象}

研究対象は, 昭和55年度に当科を受診した反復 性扁桃炎患者 (239例)のうち, 昭和55年 4 月現在, 小学校 2 年生から 5 年生までの児童で，鍼治療後 1 年間の経過を観察できた症例と，これら児童が 昭和55年度に通学していた学校の同学年で，鍼治 療を行っていない反復性扁桃炎患児である。

2. 方 法

(1) 調查方法

対象となる小学生が，昭和55年度在学してい た小学校長に対し依頼状を送付し，校長の了 承が得られた学校について，学校に保管され ている資料の中から，出席日数・年席日数・ 身体測定・健康診断について調查した。

(2) 調查項目の範囲 出席日数・欠席日数は，鍼治療を行った患児 については，鍼治療を行った日を含め，さか のぼること 12 月を鍼治療前 1 年間とし，鍼 治療を行った次の月から 12 力を鍼治療後 1 年間とした。鍼治療を行っていない患児につ いては，同学年の鍼治療を行った患児と同様 の基準で，鍼治療前に相当する 1 年間と，鍼 治療後の 1 年間に相当する期間について調査 した。

身長・体重・胸囲・坐高は，鍼治療を行っ た患児も銊治療を行っていない患児も，昭和 $54 \cdot 55 \cdot 56$ 年度の身体測定の結果を調査した。

\section{III 結 果}

今回の研究における対照群として設定した鍼治 
療を行っていない反復性扁桃炎患児については, 学校に保管されている資料において，健康診断の 結果反復性扁桃炎と記載されている児童あるいは 扁桃炎の発熱による欠席とその理由が明記されて いる児童を調査の基準としたが，これら基準で鍼 治療を行っていない反復性扁桃炎患児を抽出する ことはできなかった。そこで，厳密な意味で対照 群としては問題があるが，学校に保管されている 資料のうち, 昭和55年度の健康診断の結果扁桃肥 大と記載されている児童を選び，これを対照群と し鍼治療を行った扁桃炎患児と比較した(以下, 銊 治療を行った扁桃炎患児を鍼治療扁桃炎患児，扁 桃肥大児を非鍼治療扁桃肥大児と略す)。昭和58年 1 月から 5 月までに調查が終了した例数は，鍼治 療扁桃炎患児は94例中22例，非銊治療扁桃肥大児 は19例であった。図 1 は，鍼治療扁桃炎患児の昭 和 54 年度 1 年間(鍼治療前 1 年間)の年間久席日数 と, 非鍼治療扁桃肥大児の昭和 54 年度 1 年間 (同校 同学年の鍼治療扁桃炎患児と同じ期間を 1 年間) の年間久席日数と，都内 $\mathrm{S}$ 校の全児童の昭和 50 年
度年間欠席日数の平均を，それぞれ学年別に示し たものである。

都内 $\mathrm{S}$ 校全児童の学年別欠席日数の平均は， 2 年生が7.1日， 3 年生が 8.0 日， 4 年生が8.0日, 5 年生が6.7日である。

非鍼治療扁桃肥大児の欠席日数は，都内 $\mathrm{S}$ 校の 平均值に類似し，19例の平均は6.3日である。鍼治 療扁桃炎患児の欠席日数は，都内 $\mathrm{S}$ 校および非鍼 治療扁桃肥大児より多く，22例の平均は 14.0 日で ある。図 2 は, 鍼治療扁桃炎患児の昭和 54 年度( 鍼 治療前 1 年間)の欠席日数と, 昭和 55 年度(鍼治療 後 1 年間) の欠席日数および非鍼治療扁桃肥大児 の同期間の欠席日数を示したものである。銊治療 扁桃炎患児 22 例中，鍼治療前 1 年間の欠席日数か 10 日以上の例は11例であるが，このうち10例は銊 治療後年間欠席日数が減少した。22例の平圴は, 14.0日から6.5日に減少した。

非銊治療扁桃肥大児19例の平均は6.3日から5.1 日であった。図 3 は，鍼治療扁桃炎患児と非鍼治

\section{年消灭笘日数}

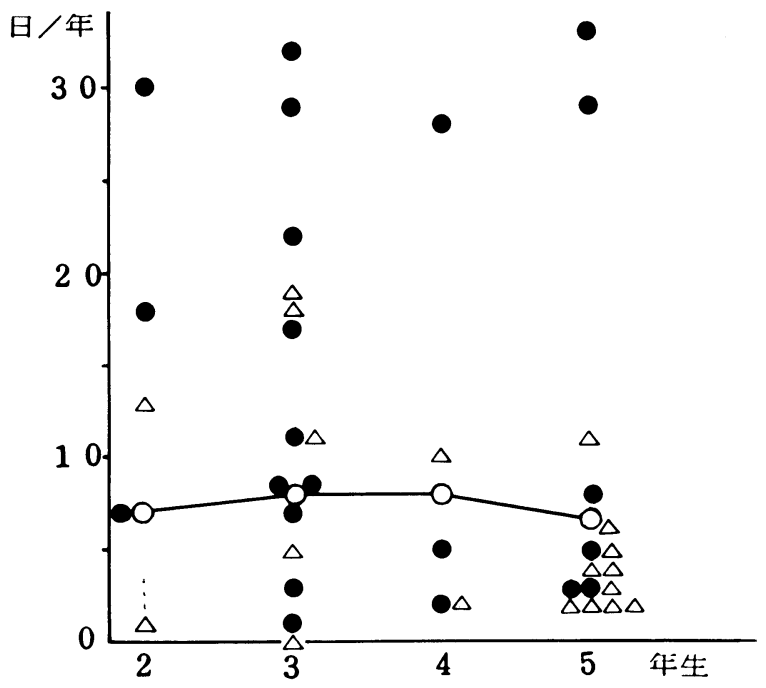

図 1 銊治療扁桃炎患児·非銊治療扁桃肥大児·

$\mathrm{S}$ 校全児童の学年別年間欠席日数

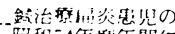

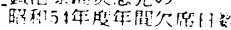

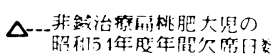
○ー-者内 $\mathrm{S}$ 校昭和 50 年度
学年別平均欠席日政

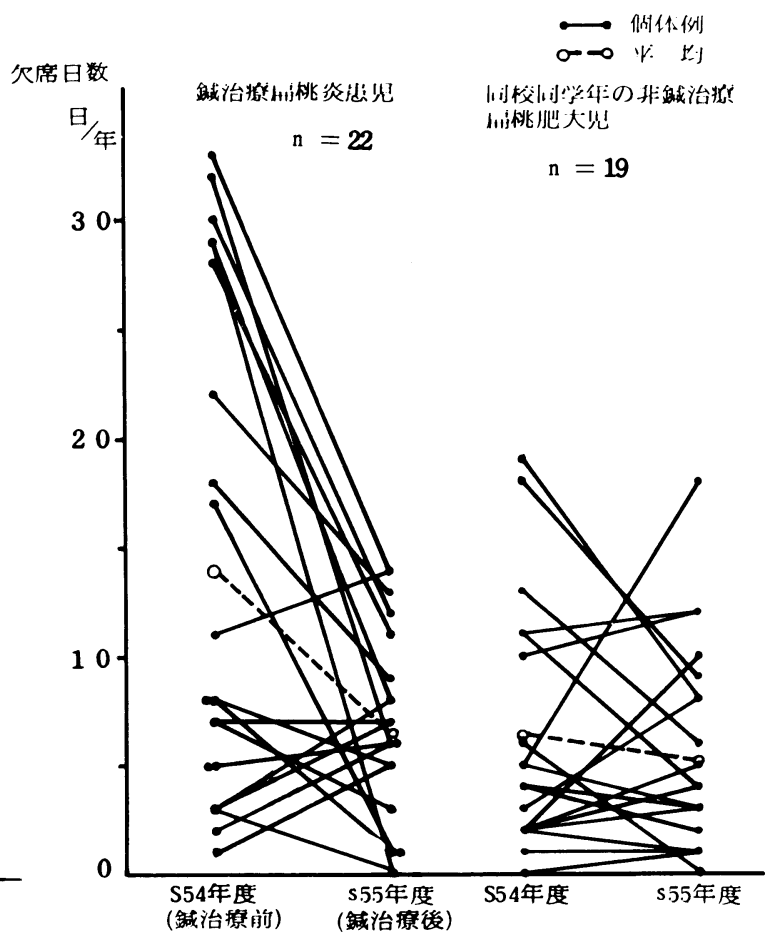

図2 銊治療扁桃炎患児と非銊治療扁桃肥大児 の年度別欠席日数 
療扁桃肥大児および，学校保健統計による全国児 童の昭和55年度の体格 (身長・体重・胸囲・坐高) を示したものである。いずれの資料も各学校で学 年初め( 4 月から 6 月)に行われる身体測定の結果 を採用しており，図示した結果は，銊治療開始時 と解釈できる。非銊治療扁桃肥大児の体格は, 全 国平均と類似した数值を示している。
鍼治療扁桃炎患児の体格は，全国平均に比較し て低值を示すものが多く，身長と体重について検 討すると， 2 年生では 2 例中 2 例が両指標とも低 值を示し， 3 年生 6 例では，身長は 2 例が体重は 5 例が低值を示し， 4 年生 3 例では身長は 2 例が 体重は 3 例が低值を示し， 5 年生 3 例では身長は 2 例が，体重も2 例が低值を示した。図 4 ・図 5

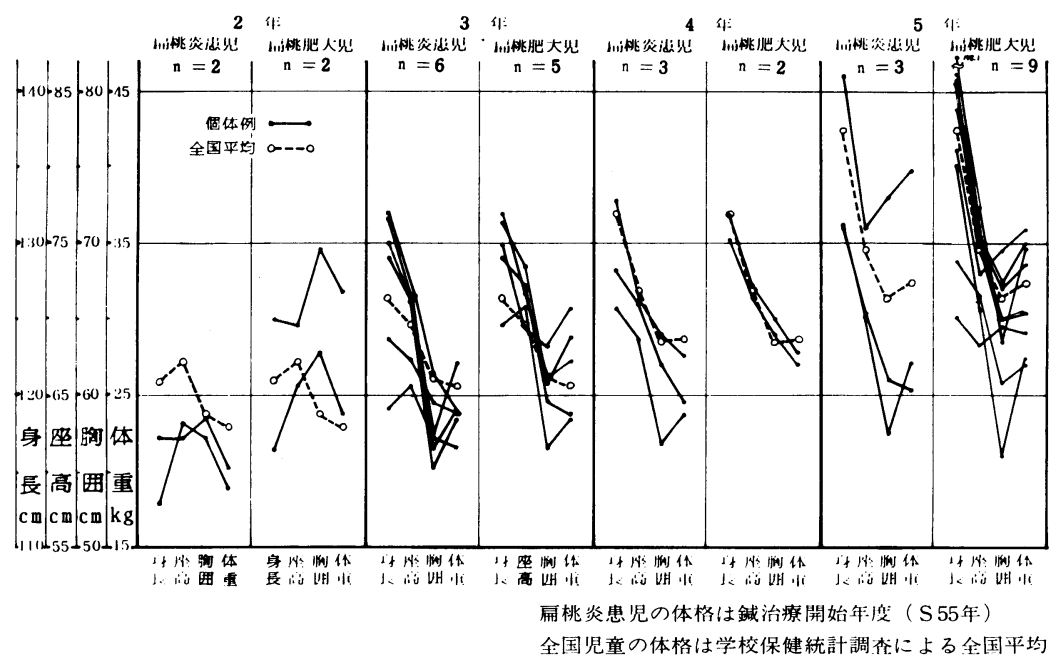

図3 銊治療扁桃炎患児·非銊治療扁桃肥大児· 全国児童の昭和55年度学年別体格

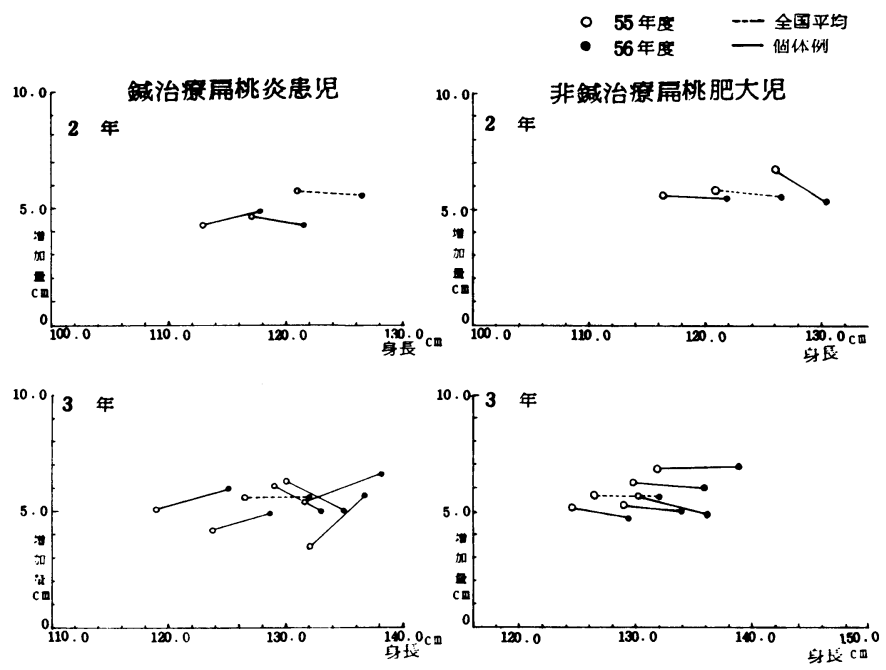

図4銊治療扁桃炎患児·非銊治療扁桃肥大児・ 全国児童の学年別年間身長増加量 
は, 銊治療扁桃炎患児と非鍼治療扁桃 肥大児について，昭和54年度と昭和55 年度の身長増加量をそれぞれ全国平均 と比較したものである。○印の $\mathrm{x}$ 軸は 昭和55年の身長を, $\mathrm{y}$ 軸は昭和54年か ら昭和 55 年まで 1 年間の身長増加量を 示し, -印の $\mathrm{x}$ 軸は昭和56年の身長を， $\mathrm{y}$ 軸は昭和 55 年から昭和 56 年まで 1 年 間の身長増加量を示している。グラフ の傾きが右上りを示すものは, 鍼治療 後1年間(昭和55年度 1 年間)の方が, 鍼 治療前 1 年間(昭和 54 年度 1 年間) より 身長増加量が大きいことを示し, 全国 平均より傾きが大きいものは昭和 55 年 度 1 年間の身長增加率が全国平均を上 回っていることを示している。

非鍼治療扁桃肥大の身長増加率は, 全国平均に近い傾向を示している。

鍼治療扁桃炎患児の身長増加率は, 2 年生で 2 例中 1 例が, 3 年生で 6 例 中 4 例が, 4 年生で 3 例中 2 例が, 5 年生で 3 例中 1 例が全国平均の増加率 を上回った伸びを示した。

図 6 ・図7は, 体重増加量を示した もので，グラフの書き方は図 4 ・図 5 と同じである。非鍼治療扁桃肥大児の 体重増加率は, 全国平均に近い傾向を 示している。鍼治療扁桃炎患児の体重 増加率は, 2 年生で 2 例中 1 例が， 3 年生で 6 例中 4 例が, 4 年生で 3 例中 3 例が, 5 年生でもともと肥満傾向の あった 1 例を除き 2 例中 1 例が全国平 均の増加率を上回った。鍼治療扁桃炎 患児の体格は, 全国平均に比較して未 発達の症例が多く, 鍼治療後 1 年間の 発育は，14例中 6 例が身長・体重とも に14例中 2 例は身長のみに，14例中 1 例に体重のみに全国平均を上回る増加 を認めた。
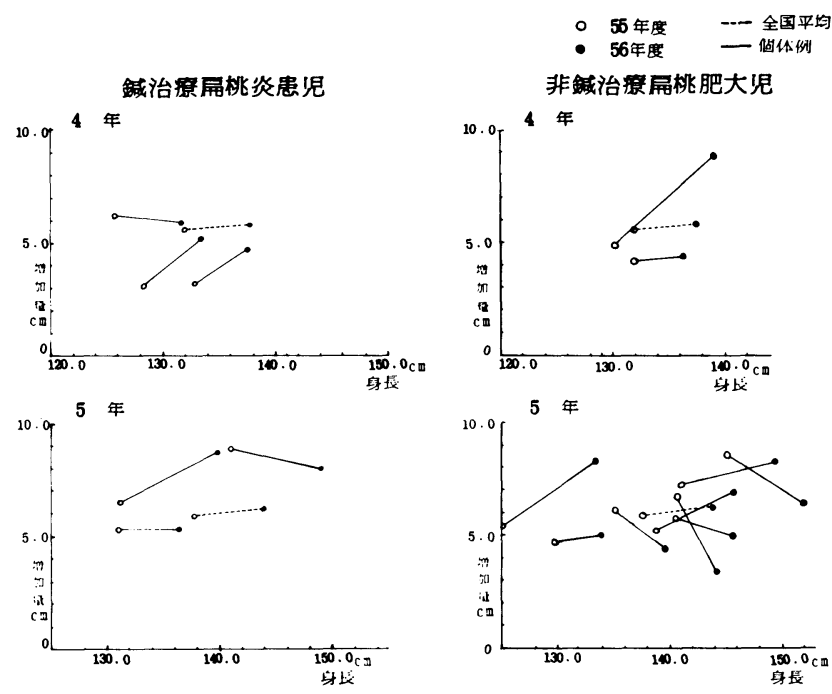

図5銊治療扁桃炎患児·非銊治療扁桃肥大児· 全国児童の学年別年間身長増加量
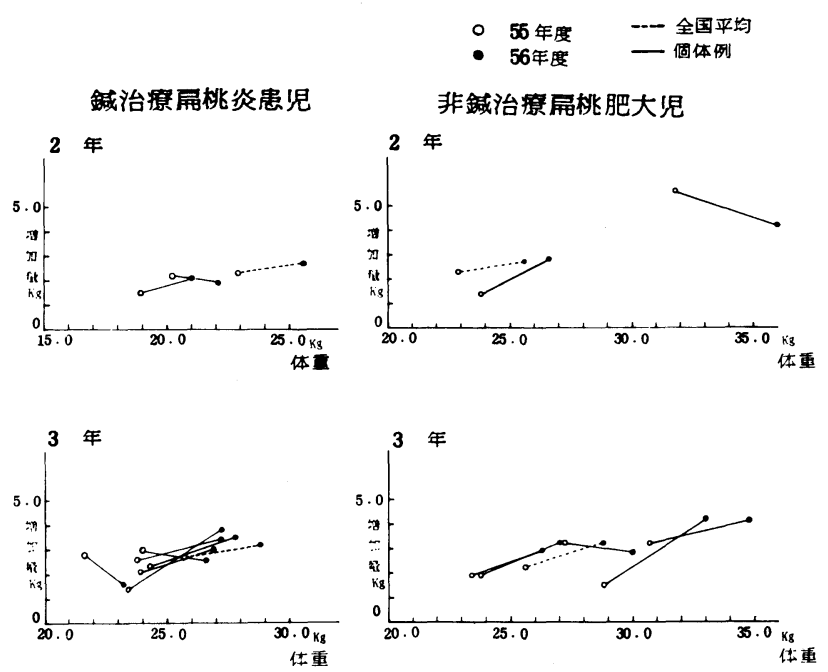

図6 銊治療扁桃炎患児·非銊治療扁桃肥大児· 全国児童の学年別年間体重増加量 
銊治療局桃炎患览
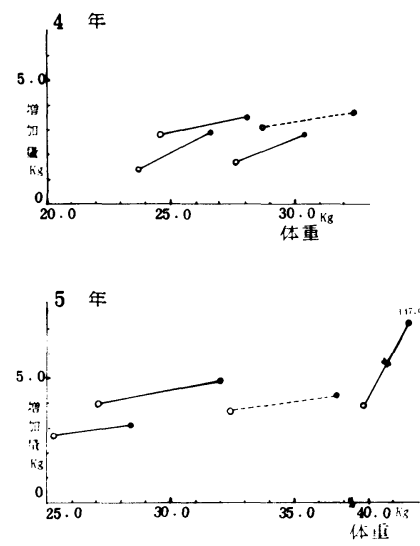

○ 55 年度 …- 全国平均

- 56 年度一优体例

非鍼治療屏桃肥大児
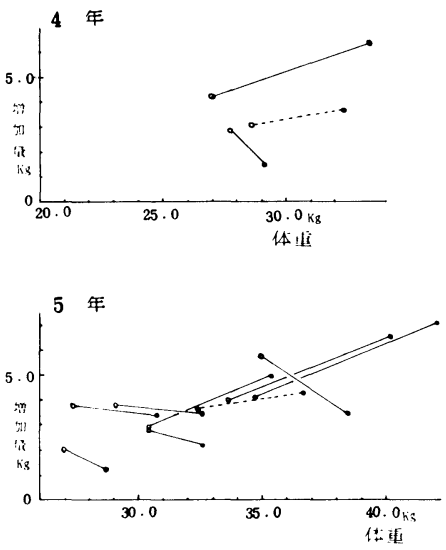

図7 銊治療扁桃炎患児·非銊治療扁桃肥大児・ 全国児童の学年別年間体重増加量

\section{IV 考察}

学校保健統計による扁桃肥大被患率は, 小学生 低学年をピークとして直線的に減少する。また扁 桃の機能は幼児期に最も盛んである。これらのこ のことから，扁桃疾患には自然治癒が大きく影響 していることが推察される。

そこで今回は，鍼治療を行った反復性扁桃炎児 と鍼治療を行っていない反復性扁桃炎児の久席日 数を比較して, 発熱の再発子防効果と自然治癒と の関係を明らかにすることを目的として研究を行 った。しかし，以下の理由により調查に対する協 力が得にくく，特に銊治療を行っていない反復性 扁桃炎児のデー夕は集められなかった。

1. 3 年前のデータであるため, 調查に人的・時 間的負担が大きすぎること。

2. 調査時期が年度末であったこと。

3. 昭和55年当時の担任教諭 - 養護教諭が転任し ている場合が多かった。

4. 反復性扁桃炎児の教育上・発達上の問題に対 する認識不足。

5. 研究に対する認識の相違から学校長の承認が 得られなかった。

6. 学校における保健関係の資料には, 扁桃肥大
の記録はあるが，卌桃炎の記録がほとんどない こと。

以上のことから，鍼治療を行った扁桃炎児の資 料は収集できたが，鍼治療を行っていない扁桃炎 児については，資料を収集することができなかっ た。そこで厳密な意味では問題があるが，銊治療 を行っていない扁桃肥大児について比較検討した。

図１において扁桃炎児の久席日数が，扁桃肥大 児および全児童より多いことは，反復性の発熱に 起因するものと考えられ，またこのことは例え自 然治癒するといえども，小児に発熱により学校を 欠席させざるを得ない状況を継続させることには, 教育上大きな問題があると考える。図 3 において, 反復性扁桃炎児の体格が, 扁桃肥大児, 全国平均 に比し劣っていることは，成長過程にある小児の 健康管理上問題があり, また自然治癒力の低下を も推察させるものである。図 4〜 7 に示すように 鍼治療の結果, 体重・身長ともに増加率が全国平 均よりやや上回ったことは, 治効メ力二ズムの解 明の上で 1 つの示唆を与えたものと考える。

\section{V 結 論}

鍼治療による反復性扁桃炎の発熱の再発予防効 果において，自然治癒の影響を明らかにする目的 
で研究を行った。対象は昭和55年度に再発予防を 目的として銊治療を行った小学生のうち，1年間 の経過を確認できた症例と同年に同校同学年生で, 鍼治療を受けていない扁桃炎児および扁桃肥大児 である。これら対象者について学校長の承諾を得 て, 学校に保管されている保健関係資料および出 席簿から, 昭和 55 年度 1 年間の出席日数および欠 席日数，55年度および56年度の身長・体重・胸囲・ 坐高について検討した。その結果以下の結論を得 た。

（1）種々の理由により，鍼治療を行っていない 扁桃炎児の資料が収集できなかった。

（2）鍼治療を行った扁桃炎児資料は22例，扁桃 肥大児の資料は19例であった。

（3）鍼治療前 1 年間の欠席日数は, 鍼治療を行 った扁桃炎児では平均14.0日であり, 扁桃肥 大児では6.3日であった。

（4）鍼治療後 1 年間の欠席日数は，鍼治療を行 った扁桃炎児では平均 6.5 日であり, 扁桃肥大 児では平均5.1日であった。
（5）鍼治療を行った扁桃炎児の体格は，銊治療 前に㧈いて全国平均より低值を示すものが多 かった。

（6）鍼治療後 1 年間の体格の増加率は, 鍼治療 を行った扁桃炎児では全国平均の増加率に比 べて14例中 6 例が身長・体重ともに，2 例が 身長のみ，1例が体重のみ上まわる上昇を示 した。

\section{引用交献}

1）飯高秀美ほか：児童の欠席傾向の両年度間の比 較研究, 健康教室 28(2);50 60.

2) 学校保健統計調查報告書, 昭和 56 年度, 文部省 昭和58年 5 月.

(干112 東京都文京区大塚3-29-1

筑波大学理療科教員養成施設) 


\title{
Clinical Study on the Prevention of Recurrent Tonshillitis by Acupuncture (III)
}

\author{
Keishi Yoshikawa, Kazushi Nishijo, Kazuhiro Yazawa, Hidetoshi Mori, \\ Tomomi Sakai, Akihiro Ogata, Kazuo Sasaki, Toshikazu Shima, Hiroki Suga, \\ Mikio Nakamura, Shuichi Katai, Katsumi Kurihara, Takeshi Tomiyasu, \\ Masahiro Kimura, Takanori Kawano, Koki Kobayashi, Koichi Wada, \\ Harumi Taketani and Akemi Yamamoto \\ School for Teachers of Acupuncture and Physical Therapy, University of Tsukuba
}

We have conducted acupuncture treatment for prevening the relapse of recurrent tonsillitis. We previously noted the effectiveness of this treatment in 121 of 239 patients treated in 1980, especially in elementary school children. In the present study, we compared the annual days of absence from school and the body dimensions of children with tonsillitis given acupuncture treatment with those having tonsillar hypertrophy chosen by a school study, although there is a question on the latter's propriety as a control group in a strict sense, in order to investigate the degree of spontaneous healing included in the preventive effects of acupuncture treatment on the relapse of recurrent tonsillitis.

By May 1983, our reseach was completed in 22 children with tonsillitis given acupuncture treatment and 19 with tonsillar hypertrophy not given such therapy. In children with tonsillitis given acupuncture treatment, the average annual days of absence from school before treatment was 14.0, which was more than that for all children in the S elementary school, and that in the year after treatment was 6.5, approximating that for all children in the school. In children with tonsillar hypertrophy not given acupuncture treatment, the average number of days of absence was close to that for all children in the $\mathrm{S}$ elementary school in both years.

Among 14 children with tonsillitis given acupuncture treatment, lower values of height and weight were noted in eight and 12 children, respectively, at the beginning of treatment, as compared with the national averages. The body dimensions of children with tonsillar hypertrophy not given acupuncture treatment were similar to the national averages. Of 14 children with tonsillitis given acupuncture treatment, an increase to a value exceeding the national average was observed with both the height and weight in six children, the height in two and the weight in one within the year after treatment.

The above results show that children with tonsillitis have a problem from the educational and developmental standpoint, even if they do not have a focal tonsil. We think that acupuncture treatment is worth attempting prior to tonsillectomy, although it is not so surely effective as tonsillectomy, when the severity of operative stress on the living body due to tonsillectomy and the burden of medical expenses and the load on the patient's family caused by hospitalization are taken into consideration. 